\title{
Priestly Dignity in the African Religious Context
}

\author{
Clement I. Osunwokeh (PhD.) (Corresponding author) \\ Dept. of Philosophy and Religion \\ Ebonyi State University, Abakaliki \\ Nigeria \\ E-mail: clementosunwokeh@yahoo.com
}

Received: July 12, 2014 Accepted: July 28, 2014 Published: September 15, 2014

doi:10.5296/ijssr.v2i2.6314

URL: http://dx.doi.org/10.5296/ijssr.v2i2.6314

\begin{abstract}
The mammoth crowd witnessed at the Christian religious gatherings on regular basis, generally tagged "Prayer Ministries", around the towns and cities, goes strongly to confirm the view of scholars of Religion and Anthropology that "Africans are naturally religious". Religion indeed makes a tremendous impact on the social, political and economic life of the Africans. The alarming rate of rush by people to these Prayer Ministries, to obtain divine favours and miracles from those of their religious leaders, whom they judge to be different from others in terms of possessing spiritual powers and aura of godliness, indicates the great influence that certain grade of leadership has in religion for them. In Christianity as in African Traditional Religion, religious leadership is generally provided by the priests. Against this back drop, this paper aims to highlight the priestly dignity as significant and important as well as symbolic for the Africans' religious wellbeing. Consequently, while it appraises the priestly dignity as a "value" recommendable to the priestly office, it alerts the priests in the African context of the danger of abuses, manipulations and exploitations susceptible to this dignity. It also proffers a conscientious effort on the part of all towards a re-adjustment of the African Christians' religious mentality to an authentic Christian faith focused on the triune God.
\end{abstract}

\section{Introduction}

The noun priest refers to a person appointed to perform religious duties and ceremonies in the Roman Catholic, Orthodox or mainstream Protestant Churches. A priest used in the above sense in this paper, is an empowered layperson, who by ordination is called to the ministry of the Gospel of Jesus Christ, the High Priest. 
Today many older Christians often talk much of aura of dignity that used to surround the priests of old known to them and as well lament that such glamour was gone. When such remarks are made, the obvious reaction is to begin to compare the priests of old with the priests of today. Running up and down in large number and almost on daily basis in search of special priests for divine favours and miracles has become a phenomenon in the African society. This has heightened the fact of religion being a big factor in the social and economic life of the masses. It is also an indication that in the judgment of the people, there is some lack in the priesthood of many priests today. Obviously the high standard of priestly dignity claimed to have been witnessed in the priests of old by these older Christians was something that was not appraised by either physical appearance, or any standard in the fulfillment of basic life necessities or ecclesiastical or civil positions.

The matter of priestly dignity is not only significant but also important to the Africans due to the indispensable role of priesthood in their religious experiences that are influenced by African Traditional Religion. Nworie illustrating priesthood in Igbo Traditional Religion which is but a part of African Traditional Religion confirms this when he writes:

The place of priesthood in Igbo religion is not dispensable, whether in form of a ritually consecrated priest with full insignia of office or a paterfamilias playing priestly roles. Hence a genuine appreciation of the concept and function of the priest with regard to sacrifice in Igbo religion is quite imperative (2011:59).

He further quotes Ekwunife as defining the priesthood in Igbo Traditional Religion as "that sacred institution in the traditional religious set-up, whose sacred officiants are ordained and dedicated for the service of a particular cult, especially in "Sacrificial" and other allied matters" (1990:2).

A clue to a location of dignity that surrounds the priesthood may be found in the theology of priesthood itself. As theological understanding of priesthood has, according to Rausch (1992), changed since the last century, the task of locating priestly dignity is no longer an easy one. For Rausch, modern biblical and historical studies have challenged the concept of priesthood, which has been dominant in the Catholic Church for almost a millennium.

Today, obviously in the Catholic Church, the emphasis is no longer on the "sacred power" which the priest was said to have possessed, setting him apart from others and giving him a unique authority. For Dulles (1990), the official theology of the priesthood has been enlarged considerably by the Second Vatican Council. He thinks the council moved beyond the emphasis on the sacred functions of prayer, worship and sacrifice, which had characterized catholic theology to declaring that ordination confers the threefold functions of teaching, sanctifying and governing, thus adding the royal and prophetic functions to the traditional cultic understanding of priesthood.

Theologians today differ as to what should be stressed in the priesthood: priests as preachers of the word of God, the cultic or sacramental ministry of the priests, and priests as leaders of 
the community of the believers. For many priests today, questions remain about their identity precisely as priests. The expectations of the laity regarding their priests have today become varied (Dulles, 1990).

For a priest of the Pre-Vatican II so long as he officiated in the Eucharistic liturgy that was essentially mysterious which made his priestly role highly visible and solemnized, his personality subsumed into the sacred ritual action, the aura of dignity and power surrounding his person was assured. The Post- Counciliar priest as he emerges in all his human weakness, the authority previously conceded automatically to his office has become increasingly something he has to earn, not merely in his liturgical role, but in the full range and extent of his ministry.

African worldview as conceived by Madu (1999) is such that religion for an African is simply not a social thing but a matter of deep concern to his whole being. A minister of religion for an African, therefore, must not be simply one like him but something else. With a religious mentality carried over from the familiar African Traditional Religion, priestly dignity is fundamentally, for the African Christians, a cherished religious value and expectation. It is on this backdrop that this paper sets to examine the issue of priestly dignity as a means of enhancing the religious fulfillment of the African persons. The paper responds to the questions: what actually constitutes priestly dignity and where can it be located? It aims at creating awareness to its reality and identity within the spectrum of the priesthood. It proffers: first as an advice, a deep spiritual and dedicated way of life whereby, being a dignified person does not conflict with Christ - like simplicity, humility, and selflessness that should characterize a priest, making him to be focused towards leading a people on to an authentic faith in triune God through the journey of earthly life on to eternity. Second, a call for the African devotees of all religious affiliations to learn to determine and appraise religious values not only from the perspective of temporal fulfillment but also from the reality of the holistic beingness of man beyond here and now, thus making God in his omnipotent will, the focus of their religion. Although the paper has a noticeable Catholic bias, its allusion and treatment of the priesthood is not limited to the Catholic Church nor to any other particular church denomination.

\section{What is Priestly Dignity?}

In the Catholic rite of ordination to the presbyterate, the prayer of consecration asks that the ordained might receive "the dignity of the order of presbyters". It may be said, therefore, that priestly dignity is conferred on the priest by ordination. Like the priesthood itself, it is something that is exercised and maintained not just a mere title. In the words of Rausch:

Essentially, part of the crisis of the ordained ministry for Roman Catholics is the fact that the one concept which has traditionally characterized the vocation and role of the ordained minister in the Catholic tradition has itself been called into question, namely, the concept of a special, "sacral" priesthood (1992:14) 
He goes on to argue that this concept understands the priest as a sacred person, set apart by ordination and in possession of special sacramental power and is often described as "another Christ (alter Christus)".

For Osborne (1988), aside from the sacramental moments, priestly dignity means, a priest striving to live out the vocation of priesthood fully, making Christ transparent within his ministry. In other words, although priests are not sacred persons, but precisely because they are public persons in the church, authorized to speak in its name, people expect them to represent Christ. A priest is said to possess priestly dignity when he apparently fulfils this expectation of the people.

Konx (1964) views the dignity of the priesthood as something that is the worth of the prize and wherein precisely the excellence of the high vocation consists. It is clear that the conformity to Christ is not "automatic" in those non-sacramental moments of the priests' official ministry. Priestly dignity is, therefore, an approach to the priesthood that stresses all existential dimensions to which places an importance on personal holiness and identity.

It is a divine presence in the priest that makes him a sacrament. According to the Fathers of the Vatican II, in one of the council's declarations (Lumen Gentium No 1.) this means that he is the sign and the instrument of the intimate union with God of mankind. According to Power (1969), it means also that he is a paradox present in the church, which is herself the greatest of the sacraments. For Power, a sacrament is on the one side part of our material, visible and tangible world; on the other side, it reaches out to God's eternity that "no eye has seen nor ear heard, nor the heart of man conceived" (1Cor. 2:9).

Priestly dignity is an intrinsic dignity. For dignity of course does not mean a style of outward behaviour, though from the careless way in which we use the English language, it would be easy to imagine that it does. Dignity is not holding oneself up very straight, or walking along very slowly, or talking in a deep voice. Dignity is worthiness, worthiness inherent in the person.

\section{The Source of Priestly Dignity}

The dignity of the priesthood has its source from the dignity of Christ. As it is known from Christ's earthly sojourn seen in the Bible, such a dignity is not in any earthly thing possessable that he possessed from birth to death, but in his essence, in the reality of his being the son of David, the great high priest, the messiah son of God. When two blind men cried out to him on the way "son of David have pity on us" (Mt 9:27), it was for Jesus, a direct appeal to the essence of his person.

The ordinary human blood of Jesus was pure, holy, innocent, and precious. When the church talks of the precious blood of Jesus, she thinks of the dignity of the person of Jesus that is in his very name. Timios the Greek word for 'precious' meaning held as of a great price, held in honour, esteemed, especially dear, throws more light to that sense of high dignity of Jesus made entirely by God's helping power. It had no stain of sin and carried no genetic defect in its chromosomes (Alsobrook, 1979). The dignity of Christ was concretized by the inspiring attitude of Mary's docility at the very moment of his conception: "Behold the handmaid of 
the Lord let it be done to me according to your will" (Luke 1:38). It was a dignity which no earthly instrument could alter; mankind, nature, luck or fate. All through his earthly life the divine will of the Father was upheld and the dignity remained intact.

The paradox of the church is present in the ministerial priesthood and so it shares in the dignity of Christ. This is also a dignity which is not determined by his human person, possession and state but by his essence as a priest "alter Christus".

Brown (1971) discovers the absence of Christian priests in the New Testament; it is striking that while there are pagan priests and Jewish priests on scene, no individual Christian is ever specifically identified as a priest. The epistle to the Hebrews speaks of the high priesthood of Jesus by comparing his death and entry into heaven with the actions of the Jewish high priest, who went into the Holy of Holies once a year with a blood offering for himself and for sins of his people (Heb. 9:6-7).

In fact, the once-for-all atmosphere that surrounds the priesthood of Jesus in Hebrews (10:12-14) has been offered as an explanation of why there are no Christian priests in the New Testament period. Kung (1967) commenting on Hebrews chapter 10 says that the significance of these ideas for the New Testament is that all human priesthood have been fulfilled and finished. So, it is logical to conclude that there is no other basis, no other point of reference that can be adduced for priestly dignity other than the highly dignified priesthood of Christ that a priest shares. So one may conclude with McGlade (1967) that there is one priesthood, that is Christ and that there is one source of the priesthood that is Christ.

\section{Awareness of Priestly Dignity}

Nash (1950) laments that many priests have no idea of their dignity as a result, they undervalue holiness like Esau, selling his birth right for a mess of porridge. He says they allow their treasure to escape them or at least they remain inappreciative of its value.

For him such lack of awareness often leads to compromise in the discharge of priestly duties and the fulfillment of priestly expectations and ideals. Nash is of the view that the divine master, Jesus of Nazareth, insists on no compromise in the priestly discipleship because his own discipleship shows no sign of compromise or inconsistency.

All the priestly celebrations that the faithful supportively and generously uphold and participate regularly in their parishes and dioceses, like ordination, anniversary of ordination and ordination Jubilee etc are all meant to create in their priests a deeper awareness of their priestly dignity. Such gestures should be encouraged not just to meet the priests' material needs and welfare but above all to enhance their awareness of the dignity of the priesthood that they share and the faithful as a dutiful tribute of honour to the dignity of the priestly character.

Awareness of the dignity of the priesthood centers a priest's attention to the correct perspective of the priesthood, which is basically living for others (Heb. 5:1). When the faithful demand that the dignity of priesthood be upheld, they are not just actually only concerned with the respect, the honour, or the favour to accord to the priests, but also their 
own fulfillment in the priesthood. They know that when the priestly dignity is maintained, their spiritual welfare is ensured, their faith enhanced and their route to Christ is cleared. That is why a pious Christian does not take interest in derogatory and damaging talks against a priest and sees it as a serious sin. That is also why a priest, who takes delight in using castigating and damaging talks against a fellow priest publicly, especially before the lay people is not only being unaware of the priestly dignity but is also being a contradiction to the enhancement of the people's faith that he stands for (cf. Ripley 1960).

McKenna (1987) who thinks the greatest need in the priesthood is "a deep living - faith" says priests should believe themselves as possessing power in the name of Jesus who gave his first followers opportunities that challenged them in impossible situations. Awareness of his dignity will make the priest to recognize who and what he represents. For McKenna often lack of faith in a priest springs from lack of awareness of his person. Because he is unaware of his dignity he often is unaware of his power from God in the sacrament of holy orders, from the Holy Spirit, who speaks to him in prayer and through the Church. A priest who is aware of his dignity above all does not inordinately find joy, fulfillment, consolation and identity in mundane things.

\section{African Religious Perception and Priestly Dignity}

To get the overview of African religious perception in the focus of this paper, it is necessary to examine it on two perspectives: religion for a traditional African and religion for an African Christian.

\subsection{Religion for Traditional African person}

For a traditional African person, religion is first and foremost a personal thing connecting his health and life, his entire world views as well as his gods/God. Huntingford (1969) illustrates this in his anthropological study of North-East Africa, when he gives a common formula of prayer among the Arusi tribe in Ethiopia thus "O God (Ya Woq) you have given me a good day, give me a good night ..., take from me all sickness and ill-luck, be propitious to me"(74-75). Over and above one supreme God, a traditional African has personal God/gods that must be worshipped and appeased. For Tasie (2005) this instills fear in him. As a follow up to the personal aspect of religion for a traditional African, Ikwuagwu (2007), however, thinks that there are no elements of formal dogma or theology or theologians in African Traditional Religion that makes it personal to its adherents when he states that traditional religion

has no missionaries and does not proselytize to convert others. There is no element of religious fanaticism, 'crusades' or 'Holy Wars' that results in killing follow human beings in the name of religion, religious conversion or defense of ones faiths. In the African Traditional Religion, people are born into it, not converted (24-25).

For a traditional African, religion is part and parcel of his life. He was born hail and healthy because a certain dead person that reincarnated in him lived well while alive on earth. He keeps alive because the gods connected with his family and community is at peace with them. 
His progress all through depends on how much he escapes the anger and victimization of the gods, as well as wickedness of evil people around him. Religion is, therefore, important to him not just for the attainment of heaven or hell when he dies but for the welfare and sustenance of his earthly life. Morality for him too is strictly observed on that line. Certain sins are directly against the earth goddess and are referred to as "Nso Ala". If one is unrepentant when he commits any of them, he faces the risk of being uprooted from the earth. To live morally keeps one at peace with the earth goddess ("Ala").

For a traditional African, religion is a practical thing involving him, his life and his environment. If he is going to toilet in the morning and falls down injuring himself he will think some spiritual power must have been responsible for it. If he has to pray, he prays spontaneously and directly to a god/God. No one teaches him the best way to pray and the wordings to use. In the traditional religion, even the existence of god is perceived in a practical sense. Supporting this Ikwuagwu writes:

In the African traditional life there are no atheists. Only a too involved would doubt or negate the existence of God, therefore, would refuse to worship him. The existence of a "strange fellow" as God is a matter that concerns not only the individual, but also the entire community. In the African Traditional Religion no one shows a child the Supreme Being. The child learns of it in the early stages of his life (2007:40).

In a moment of joy, the birth of a child into a family for instance, God is thought of as the ultimate cause of the joy. For the life of the child to be sustained God is also acknowledged. The mother of this child having to physically take care of him/her with all the necessary health-care measures is not enough for a traditional African. Something has to be done for the child to obtain the protection of God, gods or the ancestors. In a moment of sorrow, the death of a close one for instance, a god or an ancestor is believed to have caused it. During the burial care and precautions are taken to ensure another death may not occur. No perspective of living is taken for granted.

\subsection{Religion for an African Christian}

For an African Christian religion is a phenomenon one must struggle to really accept. Although his Africaness makes him naturally religious (Mbiti 1969), his Christianity is a mixed conception of religiousity. This makes Madu contend that the African Christian is in a state of dilemma when it comes to belief (1999: xv). This dilemma makes his religious comprehension divided and devoid of sharpness, solidity and clarity. Religious belief under this condition becomes one of a continuous struggle.

This serious problem was obviously from initial emergence of Christianity as a religion foreign to the Africans. The Missionaries' perception of Christianity as not only superior to all religions, but also entirely true religion made them unwilling to dialogue with other religions, including African Traditional Religion. The consequence of this was that the 
African converts to Christianity were not allowed to make input in their choice of religion and belief (Asiegbu 2006). An African Christian, therefore, received Christianity from the missionaries under what Asiegbu calls erroneous theologies of missions, which principally include three models: (1) salvation of soul model (2) implantation Christianity model (3) adaptation model.

By analysis, Christianity received in the context of "salvation of soul model" influenced by the ancient Greek philosophy of body - soul dualism has the tendency of giving pre-eminence to the soul rather than the whole person. Christianity under an implantation of Christianity model" refuses to accept that the culture of recipients has a history and a past and so has no contribution to make to Christianity. It also does not encourage local initiative. Christianity under "adaptation model" assumes that there exists only a universal Christianity that of the evangelizer from which all should merely copy. African Christian's Christianity is one received from the missionaries, who were tremendously influenced by these erroneous theologies of missions.

Consequently, for an African Christian, religion is initially received as being basically for the salvation of his soul. This is something he is simply being forced to really believe. It also means that religion is about the next world that can only be imagined. Moreover, the concept of life for the Africans makes such religious belief problematic. Obi (2009) indicates that the Africans believe that life has an important value and must be conserved; life is a continuous interplay between the two spheres of the one World inhabited by human and spiritual persons; that both spheres of existence make demands on life as guarantee of non-annihilation of the human species and preservation of generations.

When an African, who has much value for and attaches much importance to this earthly life is indoctrinated and induced to believe that his religion is basically for life in the next world, there is bound to be a revolt, a reaction and representation about his concept of religion. Indicating a clear manifestation of such revolt and a reaction, Obiagwu, writes "Consequently, one would not be surprised at the overwhelmed number of people trooping into these Pentecostal and the independent sects that promise goodies and prosperity of earthly things" (2006:183). What else other than reaction would necessitate a situation that Umorem laments of African Christians for whom religion today is "where there is a demonstration of power, speaking in tongues, anointing with oil, deliverance sessions, praise worship, healing crusades, fasting and prayers, visions and prophecies"(2006:265). For adult African Christian today there is a need to react, in fact, revolt against a religious instinct that does not touch his whole life here and now.

For an African Christian, the question: what does faith in Jesus Christ bring to the life of the suffering African? (Kanu, 2012), remains one with no single answer. This is because at the moment of suffering he is ready to seek solace to powers other than Jesus. One may therefore assert that for an African Christian the centrality of Jesus Christ in all aspects of living is not certain. This is where the challenge to his morality and his religiousity lies. Although Kanu thinks that the challenge can be tackled by a theological construction of images of Christ by 
the African theologians (2012), it is certain that the problem is not the image of Christ as presented to the African Christians, but the distorted perception of that image.

Under the above religious mentality, the African person can be very much influenced and impacted by the priestly dignity. These can either be positive or negative to which an African person can easily fall into. Here one may note the view of Obiagwu above. These Prayer Ministries are run by priests. Since these priests are readily seen by the people as possessing power and an aura of holiness, they remain at their mercy in terms of being manipulated at will. This takes the nature of being intimidated to accept every statement coming from their mouths, obey every of their orders and tolerate every of their actions. It further entails the people being stressed and compelled to undertake strenuous activities and hard decisions as penance and reparation for offences and sins, being unexpectedly and even unduly generous in the church contributions, donations and tithes and making extraordinary sacrifices to be present at the priests' church functions and prayer sessions.

Much as these may be manifest evidences of the people's acknowledgement and appreciation of the priestly dignity, they shift the priests from being what Boylan (1962:174) calls "sacerdos alter christus (priests as other Christ) participators in the priesthood of Christ", as the scenario is certainly far from being how Christ would want his priestly dignity impacted on the people. Boylan insists that the spirit of the Christians' great high priest consisted in a complete dedication of himself to the father and father's will which "found its most perfect expression on Calvary where he gave himself to suffering and death for his father's sake" (1962:176).

Although Giarchi (1966) would attribute godly powers, sacred duties, and salvific mission to priests, yet he sees them as men apart, chosen to carry out the work of Christ amongst his people. Upholding priestly dignity means as Hollings (1977) would insist, daily consciousness of being a priest. This involves projecting Christ's supremacy to the people and allowing him to take presidency in their lives. Building a scenario of fear, awe, and reverence around ones self as a priest is contrary both to the spirit of Christ and the projection of Christ (Heenan 1950) that should characterize a dignified one in the priesthood of Christ. Enang (2013) attributes to the Africans a tendency to be extremely gullible in religious matters. He illustrates this by observing that in Nigeria, despite the expressed negative views and unpleasant revelations regarding the Nigeria Independent Churches, which he thinks may not be too far from the truth, there is a steady flow of members leaving the older churches for them. With such religious mentality priestly dignity may paradoxically pose a big danger for the priests. This is because they are prone to drifting to what Enang calls "an unholy and uncompromising commercialization of Christianity" under the guise of attending to the curious faith of many flocking to them daily in their thousands. Critical minds reviewing the activities of the Prayer Ministries scattered in many towns across the country cannot but be curious and suspicious that material benefit and earthly fame are the motive behind their directors inducing their clients to continue patronizing them for spiritual services readily available in their various places or parishes. 
Asiegbu (2007:149) talks of a genre of Christianity that expressed itself in "African concepts, symbols, metaphors and thought- content, culture and world view". Consequently, citing what Hackett (1989) refers to a "religious self - determination" he points that African Christianity entails Africans determining their religion. Asiegbu goes on to argue that the lack of dialogue between Christianity and Traditional Religion in Africa that encountered each other affected African Christianity. The result is that this dialogue now goes on in the minds of individual Christians, who construct personal synthesis of what, actually, Christianity, for them, is. This poses a challenge to one holding the office of priesthood in the African Christianity. Two points to be noted here are: First the priest must accept that more often than not Christianity is far from being what the African Christians in their personal synthesis construct it to be. Second his priestly dignity involves a conscious effort to addressing this which should consist in real catechesis on the core Christian doctrines, tradition and theology. This is done with no prejudice to the current talk on enculturation that encourages Christianity dialoguing with African culture and world view. This means that when the individual Christians are attracted to the priests due to their construction of personal synthesis of what, actually Christianity, for them is, the priest should not simply rejoice that all is well or even move further to exploit the situation to his personal advantage. He should rather know that they are to be guided and directed towards real Christianity as illustrated above.

\section{Upholding the Priestly Dignity}

To the question, what was the spirit of our great high priest? Boylan answers that "it consisted in a complete dedication of himself to the father and the father's will. It found its most perfect expression on Calvary where he gave himself to suffering and death for his father's sake" (1962:176). A priest upholds his dignity by bringing his priesthood to bear with all his actions. Michael Hollings puts this succinctly thus: "that is why for instance, priesthood must be with me as my whole way of life, all the time; and its priorities, such as depending upon close relationship with Jesus Christ" (1977:98).

It is a part of priestly dignity to be prophetic in exercise of the priesthood. Unnecessary fear and inordinate prudence bring down the priestly dignity. The priests must be conscious of obvious temptation on these giving the circumstances of their position in a developing church and a developing nation. Surely there are personalities they must need by their side to support them materially in their mission and numerous projects but they must realize that these projects are secondary in their work and in their churches as church. The core issues remain human persons; bringing them to faith in Jesus Christ, to the knowledge and fear of God and the love of his kingdom. In fact, experience has shown that when people are strictly brought to the high level of faith it is amazing to see how supportive they are to the priests in their projects, even when they (the priests) go against their wishes and across their personalities by insisting on maintaining their priestly dignity.

Part of the priestly dignity is for the priest to feel the love of God in himself when others cannot feel it, or to feel the desolation of misunderstanding, indifference and lack of concern when he sits empty before God and only feel his absence. When a priest's life style reflects him as being conscious of being the consolation and hope of the masses of the poor, the 
hungry, the sick and the underprivileged, for which religion remains the sole hope in life, he is definitely said to be upholding priestly dignity.

\section{Conclusion}

It may be agreed with Leo Trese (1953) that the first duty for a priest is still to become saint. It should be believed that their sanctity will be more fruitful, more effective for others if they are cognizant of what they are. The church will be more edified and more proud of their faith when priestly dignity is dully acknowledged and upheld. It is the unique dignity of Christ which the priest possesses by virtue of ordination. It is this dignity that makes people see in him not the man but something bigger, the power of Christ, a power which mystifies yet recognizable. In the African religious context, priestly dignity is rather challenging both for the priests themselves and for the faithful people. The challenge consists in a reconciliation of two realities: 1/the priesthood identified by Sharkey (1985) as the legal office in which the occupants in humility accept speaking with an authority that is not their own and administering a service which transcends the limitation of this world. 2/A religious mentality as identified by Obiagwu (2006), which church and religion would mostly be a search for security, a means for getting immediate positive response from God to take away misfortunes and problems of life, to deliver from series of attack from the devils that fill the world and a source of obtaining healings from God. On the side of the priests this reconciliation further consists in their taking care to ensure that their priesthood does not rely on such religious mentality and play on the faith of the people entrusted to them by God. Doing otherwise has many implications among which are:

a/ an apparent approval of the erroneous religious mentality as well as according a formal encouragement to it.

b/ a projection of a heightened leadership position of the priests in a way that presents them as being up there and the people of God, the church faithful, down here.

c/ a creation of an impression of fundamentalism on the part of the priests as such will be a reflection of their interpretation of the scripture's apostolic mandate that they are concerned with.

These implications further have their consequences among which is their effect on the current model of the church as the extended family of God advocated by scholars like Chukwu (2011) and Waliggo (1994) who he (Chukwu) quoted. Chukwu thinks that the image of the church as family God strongly evokes the Africans' deep and acute sense of solidarity and relationality, which are the hallmark of the family. He would therefore see priestly dignity creating an image of the priest being a leader in the sense of the priest being up there and the people of God being down here as not proper. Walingo who cautions against the uncritical adoption of bishops and priests as substitute elders and leaders of the church as extended family of God, would see such image of priestly dignity as likely to easily slip into patriarchalism. 


\section{References}

Alsobrook, D. (1979). Understanding the Blood of Christ. Kent: Sovereign World Ltd.

Asiegbu, M. F. (2006). Spiritual Warfare and the Demonization of the Other: Missionaries, Pentecostals, Charismatics and the Popular Praxis of Demonology. The Nigerian Journal of Theology, 20(1), $85-108$.

Boylan, E. (1962). The Priest's Way to God. Dublin: Scepter Publishing Ltd.

Brown, R. (1971). Priest and Bishop: Biblical Reflections. London: Geoffrey Chapman.

Chukwu, D. O. (2011). The Church as the Extended Family of God. Bloomington, Indiana: Xlibris Publication.

Enang, K. (2012). The Nigerian Catholics And the Independent Churches: A Call to Authentic Faith. Limura: Pauline Publication, Africa.

Dulles, A. (1990). Models for Ministerial Priesthood. Origins, 20, 286-287.

Hallett, P. E. (1950). The Priest-Friend of Christ. London: D.J. Murphy Publishers Ltd.

Heenan, J. C. (1952). The People's Priest. New York: Sheed and Ward.

Hollings, M. (1977). Living Priesthood. Essex: Mayhew-McGrimmon Ltd.

Huntingford, G. W. B. (1969). The Gall of Ethiopia, the Kingdom of Kafa and Janjero. London: International African Institute,

Ikwuagwu, A. O. (2007). Initiation in African Traditional Religion. Bamberg: Echter Verlg.

Kanu, I. A. (2012). Corruption in Africa and Its Challenges for the Enterprice of Christian Theology. International Journal of Research in Arts and Social Sciences, 4(1), 492-500.

Knox, R. (1946). Retreat for Priest. New York: Sheed and Ward.

Kung, H. (1967). The Church. New York: Sheed and Ward.

Madu, J. E. (1999). Honest of African Cultural Heritage. Calabar: Franedoh publishers Ltd.

Mbiti, J. (1969). African Religion and Philosophy. Ibadan: Heinemann.

McGlade, J. (1967). The Church on Mission. Dublin: M.H. Gille and Sons Ltd.

McKenna, B. (1987). Miracles Do Happen. Dublin: Veritas Publications.

Nash, R. (1950). The Priest at His Prie-Dieu. Dublin: M.H. Gill and Sons Ltd.

Nworie, P. C. (2011). The Response of the Igboman to the Eucharistic Injunction "Do this in Memory of me": A Relevant Gospel to the Post modern Era of Individualism. Enugu: De Envoy Medca

Obi, O. D. (2009). Igbo Concept of Ndu "Life": Values and Challenges. Amamihe Journal of Applied Philosophy, 7(1), 5-28. 


\section{Macrothink}

International Journal of Social Science Research

ISSN 2327-5510 2014, Vol. 2, No. 2

Obiagwu, M. (2006). "New Religious Movements in Nigeria” in I.M Onyeocha, \& Co (eds) Contemporary Catholic Priesthood: Apostolic Courage. Owerri: Imo University Press.

Osborne, K. B. (1988). Priesthood: A History of the Ordained Ministry in the Roman Catholic Church. New York: Paulist Press.

Power, D. N. (1969). Ministry of Christ and His Church: The Theology of the Priesthood. London: Chapman.

Rausch, T. P. (1992). Priesthood Today: An Appraisal. New Jersey: Paulist Press.

Ripley, F. (1960). A Priest Forever. London: Burns and Oaths.

Sharkey, M. (1985). Journey into Priesthood. Slough: St. Paul's Publications.

Tasie, G. I. K. (2005). Religion and Moral Depravity in Contemporary Nigeria. The Nigerian Journal of Theology, 19(1), 88-98.

Trese, L. (1953). A Man Approved. London: Sheed and Ward.

Umorem, A. I. (2006). Pentecostal Challenges to Catholics: A Lesson in Collaborative Ministry. In Obinwa I. M. (ed.) Collaborative Ministry in the Context of Inculturation. Onitsha: Africana First Publishers Ltd.

Waliggo, J. M. (1994). The Church as Family of God and small Christian Communities. AMECEA 40:1

\section{Copyright Disclaimer}

Copyright for this article is retained by the author(s), with first publication rights granted to the journal.

This is an open-access article distributed under the terms and conditions of the Creative Commons Attribution license (http://creativecommons.org/licenses/by/3.0/). 